\title{
Periodismo y militancia socialista en Buenos Aires a fines del siglo XIX
}

\author{
Journalism and socialist militancy in Buenos Aires \\ at the end of the 19th Century
}

\begin{abstract}
Juan Buonuome*
Resumen: El objetivo del artículo es analizar las tensiones que la modernización periodística provocó en la militancia socialista de Buenos Aires, tal como se expresó en las ideas y prácticas periodísticas de sus principales impulsores. Para ello se privilegian dos perspectivas: 1) la historia del semanario La Vanguardia, en particular su constitución como un espacio físico y discursivo de sociabilidad política, clave para la vida partidaria en sus primeros años; 2) el contraste entre las representaciones que los socialistas se forjaron de la actividad periodística y las trayectorias que realizaron en ese terreno dos destacados dirigentes como Juan B. Justo y Adrián Patroni.
\end{abstract}

Palabras clave: Buenos Aires, Socialismo, Periodismo, Militancia.

\begin{abstract}
The objective of the article is to analyze the tensions that the journalistic modernization caused in the socialist militancy of Buenos Aires, as it was expressed in the ideas and journalistic practices of its main promoters. To this end, two perspectives are favored: 1) The history of the weekly La Vanguardia, in particular its constitution as a physical and discursive space of political sociability, key to party life in its early years; 2) The contrast between the representations that the Socialists drew from the journalistic activity and the trajectories that were made in this field by two prominent leaders such as Juan B. Justo and Adrián Patroni.
\end{abstract}

Key words: Buenos Aires, Socialism, Journalism, Militancy

Recibido: 12/05/2017

Aceptado: 20/07/2017

\footnotetext{
* Argentino. Doctor en Historia, Becario posdoctoral del Consejo Nacional de Investigaciones Científicas y Técnicas (CONICET), Profesor de la Universidad Nacional de San Martín y de la Universidad de San Andrés (Argentina). jbuonuome@udesa.edu.ar
} 


\section{Introducción}

La actividad periodística fue una dimensión central en la militancia de los socialistas argentinos a fines del siglo XIX. Junto a la edición de libros y folletos, la publicación y redacción de periódicos representó el aspecto más destacado de una labor propagandística centrada en la difusión de la palabra impresa. ${ }^{1}$ Sobre la figura del editor y la circulación de libros y folletos, se conocen sus aportes a la construcción de una "subcultura" mediante la divulgación de los principios del "socialismo científico". Se ha mostrado, en este sentido, que las iniciativas de editores, libreros y bibliotecarios en Buenos Aires fueron claves en la temprana recepción del marxismo en la Argentina. ${ }^{2}$ En esta línea también han sido analizados algunos de los periódicos más significativos del socialismo de fines del siglo XIX, como Vorwärts, El Obrero y La Vanguardia. Los trabajos disponibles han concentrado sus esfuerzos en reconstruir los perfiles de un periodismo militante que buscaba convertir la teoría marxista y socialista en un arma de construcción política. ${ }^{3} \mathrm{De}$ esta manera, se han puesto en relación los debates doctrinarios con las diferentes posiciones desplegadas en el proceso de incipiente configuración partidaria. Al igual que en el análisis de la producción y circulación de folletos, se ha priorizado una mirada centrada en el vínculo entre los periódicos y la dinámica interna del campo socialista y del emergente movimiento obrero.

No obstante, como han demostrado estudios para otras latitudes, el análisis de las experiencias periodísticas del socialismo en este período posee una enorme productividad a la hora de pensar a la propaganda socialista en relación con lógicas y actores ajenos al mundo obrero y militante. Así, por ejemplo, algunos trabajos han mostrado interesantes resultados al colocar la evolución de los órganos socialistas en conexión con las formas de organización comercial del periodismo, sobre todo, en contextos donde la industria de los periódicos se encontraba en un grado avanzado de desarrollo. ${ }^{4} \mathrm{Se}$ ha mostrado cómo el modo de funcionamiento de la "prensa burguesa" ejerció una presión sobre la naturaleza militante de los periódicos socialistas, ya sea en lo referido a sus formas de financiamiento, su nivel tecnológico y su organización legal, como en la inflexión que tenían ciertos géneros y usos del lenguaje -crónica policial, avisos comerciales, sensacionalismo- cuando eran incluidos en la trama discursiva socialista. De esta manera, el análisis de los emprendimientos periodísticos militantes ha permitido iluminar los alcances y límites del

\footnotetext{
${ }^{1}$ Régis Debray, "El socialismo y la imprenta: un ciclo vital”, New Left Review, № 46, 2007, 5-26.

${ }^{2}$ Horacio Tarcus, Marx en la Argentina. Sus primeros lectores obreros, intelectuales y científicos, Buenos Aires, Siglo XXI, 2007, 138-144 y 329-342.

${ }^{3}$ Ricardo Martínez Mazzola, "Campeones del proletariado. El Obrero y los comienzos del socialismo en la Argentina", en Políticas de la Memoria, No 4, verano 2003/2004, 91-110; Ricardo Martínez Mazzola, "El papel de la prensa en la formación del socialismo en la Argentina (1890-1912)", en VII Congreso Nacional de Ciencia Política, Córdoba, SAAPUniversidad Católica de Córdoba, 2005; Tarcus, op. cit., 144-167, 184-233; 287-301 y 307-328; Richard Walter, "The Socialist Press in Turn-of-the-Century Argentina", The Americas, vol. 37, № 1, 1980, 1-24.

${ }^{4}$ Laura Beers, Your Britain. Media and the Making of the Labour Party, Cambridge, Harvard University Press, 2010; Anne-Claude Ambroise-Rendu, “L' «autre information» dans l'Humanité: le crime, la catastrophe, le sensationnel, 19041914”, Christian Delporte, Claude Pennetier, Jean-François Sirinelli et al (eds.), l'Humanité de Jaurès à nos jours, Paris, Nouveau Monde, 2004, 43-57; Jason Martinek, Socialism and Print Culture in America, 1897-1920, London, Pickering \& Chatto, 2012; Elliot Shore, Talkin' Socialism. J. A. Mayland and the Role of the Press in American Radicalism, 18901912, Lawrence, University Press of Kansas, 1988, 1-6, 94-114.
} 
esfuerzo socialista por alcanzar y dar forma a un emergente público entre las amplias mayorías sociales. Atendiendo a estas perspectivas, el presente artículo analiza los vínculos que los militantes socialistas argentinos de fines del siglo XIX entablaron con la prensa periódica, y demuestra que sus prácticas concretas con -y en- los periódicos, así como sus representaciones sobre el rol social y político de los periódicos y los periodistas, fueron moldeadas en buena medida por el profundo proceso de modernización que atravesaba entonces el universo de la prensa periódica de la ciudad de Buenos Aires.

Los militantes que impulsaron los primeros pasos del Partido Socialista de Argentina a mediados de la década de 1890 fueron testigos, desde muy jóvenes, del rol estratégico que asumían los periódicos en la vida política a nivel nacional. En la década del ochenta habían podido observar cómo un vínculo muy estrecho entre intervención periodística y práctica política permitía a los miembros de las agrupaciones de las clases dirigentes difundir sus ideas y constituir sus propios espacios de sociabilidad. ${ }^{5}$ Todavía la idea de formar una estructura partidaria estable y orgánica no constituía un horizonte deseable para los hombres de la República Oligárquica, por lo que el periódico ocupaba, de alguna manera, su lugar. Ya en los años noventa, la relación entre periodismo y política se transformó, en parte porque la noción de partido comenzó a arraigarse en algunas zonas de la política dinamizadas por un renovado ciclo de movilización, como las que encarnaban radicales y socialistas. Pero al mismo tiempo, la aceleración del proceso de modernización periodística en base a un acrecido público lector urbano permitió a los principales matutinos, como La Prensa y La Nación, convertirse en engranajes centrales del sistema político presentándose como actores "independientes" de líderes y facciones. ${ }^{6}$

En el caso del socialismo, la prensa periódica ocupó un papel clave a la hora de impulsar la organización partidaria. En sintonía con la estrategia promovida por la Segunda Internacional, cuyo modelo provenía de la experiencia de la socialdemocracia alemana, los militantes de Buenos Aires encontraron en la creación y el sostenimiento de un periódico la llave para la transmisión de sus doctrinas y, sobre todo, para la consolidación de un partido de alcance nacional. ${ }^{7}$ En efecto, en esta década formativa, los periódicos fueron esenciales para la puesta en marcha del proceso de centralización y fusión de los clubes y asociaciones socialistas de Buenos Aires. ${ }^{8}$ En particular, el semanario La Vanguardia, fundado en 1894, jugó un rol determinante en la institucionalización del socialismo y se convirtió, tras el Congreso Constituyente de 1896, en el órgano oficial de prensa del partido recién creado.

\footnotetext{
${ }^{5}$ Paula Alonso, "En la primavera de la historia': El discurso político del roquismo de la década del ochenta a través de su prensa", Boletín del Instituto de Historia Argentina y Americana Dr. Emilio Ravignani, № 15, 1997, 35-70; Tim Duncan, "La prensa política: Sud-América, 1884-1892, Gustavo Ferrari y Ezequiel Gallo (comps.), La Argentina del ochenta al Centenario, Buenos Aires, Sudamericana, 1980, 761-783.

${ }^{6}$ Inés Rojkind, "El gobierno de la calle. Diarios, movilizaciones y política en Buenos Aires del novecientos", Secuencia, 2012, No 84, 99-123; Claudia Roman, "La modernización de la prensa periódica entre La Patria Argentina (1879) y Caras y Caretas (1898)", Alejandra Laera (dir.), Historia crítica de la literatura argentina. Volumen 3. El brote de los géneros, Buenos Aires, Emecé, 2010, 15-36.

${ }^{7}$ Raymond Dominick, "Democracy or Socialism? A case study of Vorwärts in the 1890s", Central European History, Vol. 10, No 4, 1977, 286-311; Guenther Roth, The Social Democrats in Imperial Germany. A study in Working ClassIsolation and National Integration, New Jersey, The Bedminister Press, 1963, 243-248.

${ }^{8}$ Martínez Mazzola, op. cit.
} 
Al mismo tiempo, la profundización de algunas tendencias de cambio cultural que se venían insinuando, al calor de las grandes transformaciones económicas y sociales de fines de siglo, condujeron a la militancia a ver a la prensa periódica a la luz de una nueva óptica. En un contexto marcado por la emergencia de un amplio mercado de bienes culturales y por la profesionalización de la actividad periodística, ya no alcanzaba con debatir ideas y organizar un partido. ${ }^{9}$ Los propagandistas del socialismo debían buscar medios para llevar su mensaje más allá de los militantes comprometidos, de modo de conquistar las voluntades de una amplia franja de población proveniente de los sectores medios y populares que se constituía entonces como público lector mediante el consumo de periódicos, revistas y folletos de amplia circulación.

Este desafío, expresado en las ideas y prácticas periodísticas de los socialistas, constituye el principal problema abordado en este artículo. Dos son las perspectivas privilegiadas. Una, desarrollada en el primer apartado del trabajo, es la historia del semanario La Vanguardia, en particular, su constitución como un espacio físico y discursivo de sociabilidad política, clave para la vida partidaria en sus primeros años. La otra, desplegada en el segundo y tercer apartado, es el contraste entre las representaciones que los socialistas se forjaron de la actividad periodística y las trayectorias que realizaron en ese terreno dos destacados dirigentes como Juan B. Justo y Adrián Patroni.

\section{La Vanguardia, semanario militante}

"El periódico militante se caracteriza, en definitiva, para decirlo en términos de lingüística pragmática, por un máximo de performatividad: su publicación en sí es un acto militante, su existencia es una militancia. [...] El medio poco a poco se convierte en un fin, y la relación entre el grupo o partido, por un lado y su periódico, por el otro, se invierte, haciendo a éste una condición sine qua non de aquél"10

El primer espacio al que conduce la historia -o, mejor dicho, la prehistoria- de La Vanguardia es un café en la calle Esmeralda, casi esquina Cangallo, en la ciudad de Buenos Aires. Allí, a las 8 de la noche del miércoles 2 de agosto de 1893 cuatro obreros se dieron cita con el objetivo de hallar los medios para fundar un periódico e impulsar la formación de una federación capaz de coordinar la acción gremial y política de los trabajadores. Al

\footnotetext{
${ }^{9}$ Alejandra Laera, "Cronistas, novelistas: la prensa periódica como espacio de profesionalización en la Argentina (18801910)", Carlos Altamirano (dir.), Historia de los intelectuales en América Latina I. La ciudad letrada, de la conquista al modernismo, Buenos Aires, Katz, 2008, 495-522; Sergio Pastormerlo, "1880-1899. El surgimiento de un mercado editorial", José Luis de Diego (dir.), Editores y políticas editoriales en Argentina, 1880-2000, Buenos Aires, Fondo de Cultura Económica, 2006, 1-28; Adolfo Prieto, El discurso criollista en la formación de la Argentina moderna, Buenos Aires, Siglo XXI, 2006.

${ }^{10}$ Philippe Régnier, "Le journal militant", Dominique Kalifa, Philippe Régnier, Marie-Ève Thérenty et Alain Vaillant (eds.), La Civilisation du journal. Histoire culturelle et littéraire de la presse française au XIXe siècle, Paris, Nouveau Monde, 2012, 314-315 (Traducción del autor).
} 
convencerse de que la convocatoria no tenía el eco que deseaban -a pesar de haber sido realizada a través del diario de mayor tirada de la ciudad-resolvieron disolver el encuentro. Pero antes de que abandonaran el café, un quinto hombre se presentó y se incorporó al grupo. Se trataba de un médico de 28 años, que había leído el anuncio aparecido en $L a$ Prensa y que estaba interesado en ofrecer su colaboración para la publicación de una hoja que defendiera los intereses del proletariado. El joven era Juan B. Justo y el periódico que esa misma noche decidió publicarse apareció en abril del año siguiente con el nombre de $L a$ Vanguardia.

La anécdota, relatada con mayor o menor grado de detalle por las memorias militantes, condensa un momento bisagra en la evolución histórica del socialismo en la Argentina. ${ }^{11}$ Siguiendo los términos de Ricardo Falcón, el cambio conlleva un pasaje de una era movimientista a otra partidaria. ${ }^{12}$ Después de más de una década en la que había regido una "confluencia de agolpamientos organizados sobre bases etno-lingüísticas, sindicales, mixtas o puramente políticas, con formas laxas de coordinación entre ellas y diversos grados de organicidad", se daba inicio a un proceso de institucionalización que habría de completarse en el cambio de siglo. Si bien Falcón menciona a la fundación del Partido Socialista Obrero Internacional a fines de abril de 1894 como hito de este pasaje, en varios sentidos el nuevo semanario cumplió un rol determinante en el recorrido hacia la formación de un partido orgánico y programático que se consolidaría hacia comienzos del nuevo siglo.

En primer lugar, las páginas de La Vanguardia estuvieron escritas íntegramente en español, a diferencia de lo que sucedía con otros periódicos socialistas de la ciudad como el Vorwärts o L'Avenir Social. ${ }^{13}$ Es que el sostenimiento de las identidades étnicas representaba un freno a la "nacionalización" del movimiento socialista, piedra angular de la estrategia partidaria de los miembros de la Agrupación Socialista, convocantes a la reunión del Café Francés. Ante el origen abrumadoramente inmigratorio de las clases trabajadoras de las grandes ciudades del litoral pampeano, la prédica de los militantes que editaron $L a$ Vanguardia en 1894 insistió en la necesidad de adquirir la ciudadanía argentina de modo de

11 El episodio aparece en: "Cómo se fundó La Vanguardia", La Vanguardia 50 Aniversario, Buenos Aires, La Vanguardia, 1944, 98; "El XXVI' Aniversario de La Vanguardia. La fiesta conmemorativa del Teatro Nuevo. El discurso del Dr. Repetto", La Vanguardia, 8 de abril de 1920; Dardo Cúneo, Juan B. Justo y las luchas sociales en la Argentina, Buenos Aires, Solar, 1997, 78-80; Enrique Dickmann, "El XXV Aniversario de La Vanguardia", Páginas Socialistas, Buenos Aires, La Vanguardia, 1928, 91-92; Augusto Kühn, "Apuntes para la historia del movimiento obrero socialista en la República Argentina”, Políticas de la Memoria, No 5, 2004/2005, 136 [texto publicado originalmente en Nuevos Tiempos. Revista de Buenos Aires, entre el n 1, 1 de mayo de 1916 y el n ${ }^{\circ}$ 7, 5 de agosto de 1916]; Jacinto Oddone, Historia del socialismo argentino, Buenos Aires, Centro Editor de América Latina, 1983, 21-22; Luis Pan, Juan B. Justo y su tiempo. Apuntes para una biografía intelectual, Buenos Aires, Planeta, 1991, 95-96.

${ }^{12}$ Ricardo Falcón, “Orígenes del movimiento socialista en Argentina. Prólogo. Capítulo I y II”, Cuadernos del Ciesal, № 10, 2011, 32-34.

${ }^{13}$ La Vanguardia no fue, sin embargo, el primer periódico socialista local redactado en español. Entre 1890 y 1892 (y con una segunda época en 1893) había salido El Obrero, publicado a instancias del Comité Internacional Obrero (impulsado por algunos integrantes del club socialista alemán Vorwärts, con el objeto de responder a las iniciativas del Congreso Internacional Obrero reunido en París en 1889). En un contexto de reflujo de la actividad reivindicativa, la redacción de $E l$ Obrero impulsó un debate en torno a la pertinencia de concentrar las fuerzas en el combate político por medio de un partido orgánico, siguiendo los lineamientos del programa de Erfurt adoptado por la socialdemocracia alemana en 1891. Ante las dificultades que presentaba la acción gremial en un contexto de crisis económica, se planteaba la necesidad de priorizar la acción política del proletariado frente a lo que consideraban una tendencia regresiva consistente en organizar sociedades de resistencia aisladas entre sí. 
habilitar el ejercicio del derecho al voto. ${ }^{14}$ Un paso importante en este sentido fue el cambio del nombre del partido, que dejó de ser "Internacional" y comenzó a ser "Argentino" tras el Congreso Constituyente de 1896.

Las páginas de La Vanguardia se erigieron, además, en tribuna de un debate sobre estrategia política que animaba por entonces a los círculos socialistas de Buenos Aires. En las columnas del semanario, nutridas por una sistemática política de traducción de autores de la socialdemocracia europea, abundaban los textos extensos con el tipo de desarrollo metódico y razonado que era frecuente encontrar en los folletos que componían las "Bibliotecas socialistas". 15 "Huelgas y acción política", "Proteccionismo y librecambio", "La evolución de la propiedad”, “Trabajo intelectual y trabajo mecánico”, “Qué hacer?”, "La República Argentina, la crisis agraria y el socialismo”... Estos artículos mostraban una gran amplitud de registro, confundiéndose allí la discusión teórica, el análisis de actualidad económica, política y social, y el comentario sobre el movimiento obrero y socialista local e internacional. Allí se construía un espacio de discusión relativamente acotado y conformado de lectores militantes: esto es, el puñado de obreros, estudiantes y profesionales que, al involucrarse en el proceso de institucionalización del socialismo, conocían y comprendían las discusiones que se daban en el movimiento socialista internacional.

Por otra parte, la condición de órgano de una agrupación política le daba a La Vanguardia su cargo la función de informar y coordinar sobre sus reuniones, asambleas, congresos y movilizaciones. Desde su aparición en abril de 1894 como vocero de la Agrupación Socialista de Buenos Aires (transformada en julio de ese año en el Centro Socialista Obrero), el periódico logró vincular entre sí los elementos dispersos del movimiento con la ayuda de un caudal regular de avisos e informaciones ubicado en la primera y en la última página. Durante 1895 y principios de 1896, además, se publicaron los documentos que daban sustento al proceso de institucionalización, como los proyectos de programas, estatutos y declaraciones de principios. El periódico le daba identidad al partido en ciernes. Como ha señalado Ricardo Martínez Mazzola, mientras no definía aún sus estatutos y no era reconocido por los interlocutores del socialismo, el partido era todavía una organización meramente virtual que surgía de la voz del periódico. ${ }^{16}$ Así, cuando a fines de 1895 el diario La Prensa se interesó por el movimiento socialista en la Argentina, solicitó una entrevista con la redacción del periódico y no con el Comité Ejecutivo del partido. ${ }^{17}$

No puede desconocerse, por último, el papel que le correspondió a los primeros locales de La Vanguardia como espacios de sociabilidad donde se desarrollaba la construcción partidaria. En principio las humildes instalaciones donde se realizaba la composición del periódico (la impresión se hacía en un local comercial) estuvieron ubicadas en la casa del

\footnotetext{
${ }^{14}$ Ricardo Falcón, "Izquierdas, régimen político, cuestión étnica y cuestión social en Argentina (1890-1912)", Anuario, № 12, 1986/7, 365-389; Lucas Poy, "Ciudadanía, derechos políticos y conciencia de clase. La cuestión de la naturalización de los extranjeros en los orígenes del socialismo argentino", Diálogos, Vol. 16 N², 2015, 3-29.

15 Tarcus, op. cit., 307-342.

${ }^{16}$ Martínez Mazzola, op. cit., 5-6.

17 "El socialismo en la República Argentina”, La Vanguardia, 26 de octubre de 1895, 1.
} 
militante alemán Augusto Kühn. Pero a los tres meses, el taller y la administración fueron trasladados a un local alquilado en la calle Chile 959. Según los recuerdos de Esteban Jiménez, dicho local estaba compuesto de una "espaciosa sala con dos grandes ventanas a la calle, para conferencias y reuniones obreras, y un par de habitaciones regulares, en una de las cuales se instalaron los elementos tipográficos para componer las páginas de $L a$ Vanguardia". ${ }^{18}$ Allí se organizaban reuniones gremiales, como así también "veladas político-literarias" a las que eran invitados distintos grupos socialistas, como el club Vorwärts, Les Egaux y Fascio dei Lavoratori, además de algunos artistas y escritores relacionados con la sociabilidad cultural del Ateneo. ${ }^{19} \mathrm{Si}$ bien la desconfianza de los propietarios y la endeblez financiera de los socialistas obligaron a constantes traslados en los primeros años, la existencia de este espacio de reunión fue clave. Cuando faltaba, la desorientación reinaba entre los militantes. En ocasión de un traslado forzado, Juan B. Justo escribió a José Ingenieros: "ahora está todo tan dislocado por la falta de un centro de reunión, que apenas veo a los de la administración”. ${ }^{20}$

La celebración del Congreso Constituyente del Partido Socialista Obrero Argentino a fines de junio de 1896 produjo cambios significativos respecto de las funciones del periódico y sus vínculos con el partido. En primer lugar, y como parte de la consolidación institucional y programática establecida por el congreso, el control político del periódico fue traspasado al Comité Ejecutivo del partido. Se trató de un paso fundamental para la centralización política que perseguía el grueso de los socialistas. Desde entonces, La Vanguardia debía publicarse donde residiera el Comité Ejecutivo y a través de sus páginas transmitir a las agrupaciones socialistas todas las comunicaciones. La leyenda de "Periódico Socialista Científico" que desde el primer número adornaba su frontispicio, fue reemplazada por la de "Órgano Central del Partido Socialista Obrero".

Esta dependencia formal del periódico respecto del partido puede ser, sin embargo, matizada. A partir de 1896, la expansión territorial del partido estuvo atada a la capacidad de los agentes de suscripción que La Vanguardia tenía fuera de la capital para captar simpatizantes. En 1899, La Vanguardia contaba con veintinueve agentes de suscripción por fuera de la Capital mientras que el partido tenía sólo seis centros estables. ${ }^{21}$ Pero hacia 1903, esta relación ya se había equiparado, siendo treinta y cuatro los centros, y treinta y cinco los agentes de suscripción, lo que demuestra la importancia del periódico para dar al Partido Socialista un alcance geográfico más allá de la ciudad de Buenos Aires. ${ }^{22}$

Desde fines de 1896, además, se produjeron cambios importantes en la forma de gestión económica de la empresa, que afectaron el papel que Juan B. Justo había tenido en los primeros momentos de vida de La Vanguardia como principal sostén financiero. Si bien los

\footnotetext{
${ }^{18}$ Esteban Jiménez, “Las viejas casas”, La Vanguardia 50 Aniversario, Buenos Aires, La Vanguardia, 1944, 112.

19 Allí solían asistir Roberto Payró, Ernesto de la Cárcova, Eduardo Schiaffino, Martín Malharro, Alberto Ghiraldo, Leopoldo Lugones y José Ingenieros. Sobre el Ateneo, ver: Laura Malosetti, Los primeros modernos. Arte y sociedad en Buenos Aires a fines del siglo XIX, Buenos Aires, Fondo de Cultura Económica, 2001, 347-353.

${ }^{20}$ Carta de Juan B. Justo a José Ingenieros, 28 de diciembre de 1895, Fondo José Ingenieros, CeDInCI, A-6-1.

21 "A los suscriptores del interior", La Vanguardia, 23 de septiembre de 1899, 3; "Partido Socialista", La Vanguardia, 3 de junio de $1899,4$.

22 "Partido Socialista Argentino" y "Agentes de La Vanguardia”, La Vanguardia, 6 de junio de 1903, 4.
} 
recursos iniciales con los que se puso en marcha el periódico no habían surgido exclusivamente de los bolsillos de Justo, en los meses siguientes sus donaciones extraordinarias fueron claves para impedir que se interrumpiese su publicación por falta de fondos. ${ }^{23}$ El administrador del periódico nombrado por el Congreso Constituyente, José A. Lebrón, planteó en ese contexto la necesidad de independizar la marcha de La Vanguardia respecto de la "tutela moral" que según él representaban los aportes extraordinarios. ${ }^{24} \mathrm{La}$ solución que intentó fue aggiornar al órgano socialista al proceso de modernización periodística, incorporando formas de gestión específicamente comercial, como los avisos publicitarios y la venta callejera. ${ }^{25}$ Además, impulsó la publicación semanal de "grabados de actualidad" en la portada del periódico, para "hacerlo entrar por los ojos al público" y así aumentar la venta de números sueltos en las calles, kioscos y librerías. ${ }^{26} \mathrm{~A}$ partir de entonces, la gestión económica de la empresa ganó viabilidad y autonomía, como exhiben los balances mensuales publicados por los sucesivos administradores desde 1898 .

En relación a aquello que ofrecían las páginas del periódico, pueden advertirse cambios importantes a partir de 1897. La ampliación del formato, la nueva jerarquización de las secciones, la disminución en la extensión de los artículos y la incorporación de nuevos contenidos estuvieron relacionadas con el intento por contrarrestar el papel protagónico que adquirían los "grandes diarios" porteños en el proceso de formación de un público lector extendido. ${ }^{27}$ Así, los redactores de La Vanguardia incrementaron y llevaron a la primera plana a los sueltos breve de actualidad, cuyo objetivo era incidir sobre el proceso de elaboración de noticias que a diario realizaban los matutinos más importantes de la capital. Además, introdujeron dispositivos de propaganda "menuda" dirigidas al público de "indiferentes", que recogían los tópicos de la literatura y la poesía criollista de corte popular que circulaba en folletines periodísticos y folletos a fin de siglo. Seducidos por el éxito masivo de un género que facilitaba la integración de las mayorías inmigrantes a la sociedad y a la cultura locales, algunos redactores de La Vanguardia, como Adrián Patroni, pusieron allí su esperanza para lograr despertar su atención. En ambos casos, se trataba de construir un lector popular, cuyo perfil sociocultural más bien difuso y heterogéneo coincidía con los contornos del nuevo público ampliado que compartía un acceso casi cotidiano a publicaciones periódicas de alcance masivo.

Hacia el fin de la última década de siglo, se produjo otra novedad importante en la vida del periódico y del partido: por primera vez, los socialistas contaron con un local propio que

\footnotetext{
${ }^{23}$ Acta de la Asamblea del Centro Socialista Obrero, 17 de mayo de 1895, Fondo José Ingenieros, CeDInCI, A-1-1. Enrique Dickmann, "El XXV Aniversario de La Vanguardia”, Páginas Socialistas, Buenos Aires, La Vanguardia, 1928, 93-94; Kühn, op. cit., 135.

${ }^{24}$ José A. Lebrón, "Dos palabras", La Vanguardia, 26 de diciembre de 1896, 2-3.

25 "Partido Socialista. Comité Ejecutivo Nacional", La Vanguardia, 27 de julio de 1896, 1; Juan A. Solari, La Vanguardia. Su trayectoria histórica. Hombres y luchas, Buenos Aires, Afirmación, 1974, 20.

26 "Nuestros grabados", La Vanguardia, 13 de julio de 1895, 2; "Vida nueva", La Vanguardia, 2 de enero de 1897, 1; Jacinto Oddone, "La «vía crucis» de La Vanguardia", La Vanguardia. A 1 año de su clausura, Buenos Aires, Comisión de Prensa del Partido Socialista, 1948, 37.

27 Juan Buonuome, “"Los socialistas argentinos ante la 'prensa burguesa'. El semanario La Vanguardia y la modernización periodística en la Buenos Aires de entresiglos", en Boletín del Instituto de Historia Argentina y Americana "Dr. Emilio Ravignani", Tercera Serie, No 46, 2017, 147-179; Juan Buonuome, "Fisonomía de un semanario socialista: La Vanguardia, 1894-1905”, en Archivos de historia del movimiento obrero y la izquierda, № 6, 2015, 11-30.
} 
dio cobijo a las instalaciones de La Vanguardia y fue el centro de su sociabilidad militante por un dilatado período de seis años. En la nueva casa que ellos mismos construyeron en la calle México 2070 residían, al mismo tiempo, el taller, la redacción y la administración de La Vanguardia, el Centro Socialista Obrero, el Comité Ejecutivo del Partido, el Centro Socialista de Estudios, la oficina de la Asociación Obrera de Socorros Mutuos, la Cooperativa Obrera de Consumos y la sede de numerosas sociedades de resistencia. El local contaba además con una librería, un café, una biblioteca, un salón de conferencias y reuniones, un consultorio médico de atención gratuita y un centro de asesoramiento para todos aquellos que desearan adquirir la carta de ciudadanía gratuita. ${ }^{28}$ Los socialistas se animaban a hablar de su "pequeña Casa del Pueblo", en alusión a la Maison du Peuple que los socialistas belgas habían erigido en Bruselas, donde se instalaban los almacenes de su imponente cooperativa y donde se desenvolvía el grueso de su sociabilidad política y cultural. ${ }^{29}$ Las impresiones de Adrián Patroni al entrar a este "palacio" modernista durante su gira europea de 1903 son elocuentes respecto de la admiración que los militantes de Buenos Aires guardaban por ese gran local socialista. ${ }^{30}$ Aunque la versión porteña era modesta, en Santiago de Chile los redactores del periódico socialista La Rebelión la consideraban un modelo, junto con las de Montevideo y Bruselas. ${ }^{31}$ Pero los animadores de La Vanguardia tenían en su propia ciudad un establecimiento que les despertaba tanta o mayor envidia. Se trataba del edificio que La Prensa, el diario de mayor tirada de toda Sudamérica, había inaugurado en 1898 en la moderna Avenida de Mayo. Al ofrecer en forma gratuita asistencia médica y jurídica, biblioteca y salones para realizar reuniones y conferencias, La Prensa se había constituido en un verdadero espacio público del que participaban distintos grupos sociales, incluidas las clases populares y obreras. ${ }^{32}$ De hecho, este importante edificio de la ciudad se había ganado el mote de "Casa del Pueblo", algo que los socialistas impugnaron en forma repetida, y con una buena dosis de amargura, desde las páginas de La Vanguardia.

Como sugiere su ansiedad respecto a los salones de La Prensa, el socialismo sostuvo en estos años la idea de que el espacio en torno al cual debía girar la sociabilidad política y cultural de su militancia eran las instalaciones del periódico: el taller, la redacción y la administración, y sus extensiones naturales, el café, la librería y el salón de conferencias. A diferencia de lo que se observaba entonces en el socialismo belga, donde las casas del pueblo tuvieron un origen basado en la función cooperativa, o en el socialismo español, donde ellas surgieron con objetivos variados de socialización cultural, en Buenos Aires, el núcleo inicial de este espacio estuvo, en forma indiscutida, en la actividad periodística y

28 "Centro Socialista Obrero", La Vanguardia, 4 de febrero de 1899, 1.

29 “En Bélgica. La Casa del Pueblo de Bruselas”, La Vanguardia, 1 de abril de 1899, 1; "La Casa del Pueblo de Bruselas", La Vanguardia, 10 de junio de 1899, 2. En abril los belgas erigieron un edificio construido por el arquitecto modernista Víctor Horta. Jean Delhaye, La Maison du Peuple de Victor Horta, Bruxelles, Atelier Vokaer, 1987.

30 Adrián Patroni, "Por Europa", La Vanguardia, 26 de septiembre de 1903, 3.

31 "Las sociedades de Socorros Mutuos", La Rebelión, noviembre de 1901, 1.

${ }^{32}$ Ver, por ejemplo: "Se salvó la humanidad", La Vanguardia, 19 de noviembre de 1898, 2. "Los milagros y La Prensa", La Vanguardia, 3 de diciembre de 1898, 1: Hernán Gómez, "Los diarios como espacios públicos. La Prensa en la vida social de Buenos Aires a comienzos del siglo XX”, Intersecciones en Antropología, No 9, 2008, 261-274. 
editorial. ${ }^{33} \mathrm{Y}$ aunque los lazos construidos allí se vieron inmersos progresivamente en las redes de sociabilidad que forjaban unas estructuras partidarias cada vez más sólidas y extendidas, el periódico siguió siendo, entrado el siglo XX, en "el motor de la actividad del partido". 34

\section{Periodismo militante en tiempos de profesionalización}

"Los primeros socialistas que escribieron La Vanguardia también la componían: eran al mismo tiempo redactores y tipógrafos; los mismos la doblaban, le pegaban la faja y llevaban los bultos al correo". ${ }^{35}$ La descripción retrospectiva de Enrique Dickmann buscaba resaltar la entrega de los fundadores de La Vanguardia, militantes periodistas cuya desinteresada labor se mantenía ajena a la especialización profesional que caracterizaba al proceso de modernización del periodismo en el cambio de siglo. Según esta concepción, la militancia periodística conllevaba la realización de múltiples funciones, sin esperar a cambio más que un retorno monetario "simbólico", en el mejor de los casos. ${ }^{36}$ Por otra parte, la descripción enfatizaba la ausencia de distinción entre quienes concebían los contenidos del periódico y aquellos que realizaban labores materiales como su composición y su preparación para distribuirlo. Se podía encontrar en esa referencia un tópico recurrente de la tradición socialista como es la amalgama entre el trabajo intelectual y el trabajo manual encarnada en la figura del obrero gráfico. ${ }^{37}$

Los socialistas argentinos exaltaban el rol del periodista militante en un contexto en el que la actividad periodística se hallaba en un incipiente proceso de profesionalización. ${ }^{38}$ A fines de siglo, escribir en un diario en la ciudad de Buenos Aires empezaba a aparecer cada vez más como una ocupación que permitía un cierto posicionamiento social y cultural a quien, aún sin contar con un específico capital político o familiar, había adquirido las competencias necesarias para trabajar en un periódico. Esta profesionalización en ciernes generaba instancias formales e informales de sociabilidad y asociación. Por una parte, las redacciones de los diarios (y los cafés cercanos a ellas) se convertían en el núcleo de relaciones de nuevo tipo, que giraban en torno al trabajo periodístico y que implicaba una forma de identidad específicamente urbana con vínculos con la bohemia literaria y los

\footnotetext{
${ }^{33}$ Francisco de Luis Martín y Luis Arias González, Casas del Pueblo y centros obreros en España, Madrid, Editorial Pablo Iglesias, 2009, 76-133; Jean Longuet, "Le Parti Ouvrier Belge”, Adéodat Compère-Morel (Dir.), Encyclopèdie Socialiste, Syndicale et Cooperative de L'Internationale Ouvrière, Paris, Aristide Quillet, 1913, 118-121.

${ }^{34}$ Jiménez, op. cit., 112.

${ }^{35}$ Dickmann, op. cit., 93.

${ }^{36}$ Una nota sobre el funcionamiento de la prensa socialista en Alemania aparecida en La Vanguardia expresa bien esta concepción: "En general los redactores socialistas tienen un trabajo mucho más considerable que los de los diarios burgueses. Tienen que estar a la disposición de los camaradas como oradores, tienen que asistir a todas las reuniones, dar informes en cualquier momento que sea. El trabajo es mucho más duro que en la prensa burguesa. De manera que se ha podido decir de muchos redactores de nuestra prensa: 'Los que quieren luchar continua y regularmente para la realización de la jornada de ocho horas, están obligados a trabajar diez y seis"”. "La prensa socialista en Alemania", La Vanguardia, 3 de agosto de 1901, 2

${ }^{37}$ Según Debray "el tipógrafo profesional ocupa un lugar especial como nexo de unión entre la teoría proletaria y la condición obrera; se trata del mejor medio para la intelectualización del proletariado y la proletarización del intelectual, doble movimiento del que surgieron los partidos obreros. Un tipógrafo es la quintaesencia del «intelectual obrero o del obrero intelectual», el tipo ideal que se convertiría en el eje del socialismo: «el proletario consciente»". Debray, op. cit., 6. ${ }^{38}$ Laera, op. cit.
} 
círculos políticos e intelectuales. Por otra parte, emergían formas de asociación profesional, cuyo principal exponente fue el Círculo de Prensa fundado en 1896, en las que el periodismo era visto como una actividad con fines propios y ya no como un trampolín para la carrera política. Aunque el deseo de contar con una jubilación era uno de las razones para entrar en estas asociaciones, no se trataba de un verdadero sindicalismo, ya que convivían allí los dueños de los diarios y los redactores asalariados. ${ }^{39}$

Este proceso se daba en forma paralela en distintas urbes del mundo occidental pero el posicionamiento de los militantes socialistas ante él no era el mismo en todos los casos. ${ }^{40}$ En Francia, donde los cuadros principales e intermedios de los partidos y agrupaciones socialistas estaban compuestos en forma mayoritaria por escritores, abogados, médicos, profesores y estudiantes universitarios que con frecuencia trabajaban por un sueldo en grandes periódicos comerciales de orientación republicana, se realizaba un gran esfuerzo por defender y organizar la profesión periodística como un trabajo digno y necesario. Así, un grupo de militantes encabezado por Victor Jaclard, director de la Revue Socialiste, impulsaba en los años noventa la creación de un Sindicato de Periodistas Socialistas y de una Cámara Sindical de Periodistas con el objetivo de mejorar la situación material e incrementar el reconocimiento de la profesión. ${ }^{41}$ En los considerandos de estas iniciativas, a mitad de camino entre lo político y lo corporativo, se insistía en la imagen del periodista como un trabajador que debía hacer frente a las condiciones de existencia que el capitalismo le había impuesto al mundo de los grandes diarios. ${ }^{42}$

Por su parte, los socialistas argentinos, si bien reconocían -como casi todo el movimiento socialista internacional- que tanto intelectuales como obreros manuales eran trabajadores, construyeron representaciones muy negativas sobre los periodistas que trabajaban a sueldo en la prensa "burguesa". Los redactores de La Vanguardia establecieron una estricta división entre aquel que acudía a la prensa para publicitar las ideas del socialismo y aquel que "vendía" sus servicios a un diario comercial a cambio de una retribución monetaria. En las páginas del semanario partidario, se solía prestar atención a la figura del redactor anónimo de noticias y sueltos nacido al calor del proceso de profesionalización y especialización de la actividad del cambio de siglo. “¿Quiénes son los periodistas?”, se preguntaba Adrián Patroni: "en su mayoría son asalariados que tienen que vender su pluma y escribir en oposición a sus convicciones, si es que no quieren morirse de hambre". ${ }^{43} \mathrm{Al}$ interior de la cultura socialista, la idea de "proletarización" del intelectual era a menudo exaltada en la medida en que complementa el proceso de "intelectualización” del trabajador

\footnotetext{
${ }^{39}$ Ley de Jubilación de Periodistas, Buenos Aires, Publicaciones del Círculo de la Prensa, 1941, 5.

${ }^{40}$ Sobre este proceso para el caso francés, resulta interesante el análisis de Christophe Charle, Le siècle de la presse: 1830-1939, Paris, Ed. du Seuil, 2004, 149-152.

${ }^{41}$ L'Organisation Corporative et la Presse Socialiste. Syndicat des Journalistes Socialistes et Chambre Syndicale des Journalistes, Paris, Libraire de la Revue Socialiste, 1893. Otros dirigentes socialistas destacados participaron también de esta iniciativa, como Jules Guesde, Benoît Malon, Aristide Briand, Charles Longuet, Fernand Pelloutier y Alexandre Millerand.

${ }^{42}$ Ibid., 3-11.

${ }^{43}$ Adrián Patroni, "La guerra con Chile, la prensa mercantil y los obreros”, La Vanguardia, 6 de julio de 1895, 1.
} 
y favorecía, así, la unión entre la teoría proletaria y la condición obrera ${ }^{44}$. Pero el criterio era diferente a la hora de considerar al periodista profesional de la "prensa grande". Antes que un compromiso ético-político con la causa obrera, proletarización significaba la renuncia a los principios para conseguir a cambio un beneficio económico. Se trataba de una impugnación moral al ejercicio del periodismo como "un simple medio de vida" antes que como una "misión", que se resumía en la figura del "bufón moderno": "el bufón de las pasadas épocas, con sus ridículas contorsiones y sus muchas estúpidas ocurrencias, hacía las delicias de su dueño: el rey. El periodista de los tiempos modernos, con sus bajas adulaciones y sus siempre hipócritas ingenuidades hace la ventura de su amo: el capitalista". ${ }^{45}$

Pero más allá de las representaciones sobre la figura del periodista: ¿Quiénes escribían La Vanguardia? ¿Cuál era su perfil social y profesional? ¿Qué tipo de vínculos establecieron con la actividad periodística? Si se observa la composición del staff de redactores en sus primeros años, uno de los rasgos que más rápidamente salta a la vista -además de la completa ausencia de mujeres-, es el equilibrio entre quienes se reclutaban en los sectores medios profesionales (en general, universitarios) y quienes tenían orígenes más modestos y vivían (o habían vivido hasta hace poco) de un oficio manual. ${ }^{46}$ En este sentido, la conformación relativamente heterogénea en términos socioprofesionales que caracterizaba a las filas del Partido Socialista se reflejaba también en forma más o menos directa en el cuerpo de redactores de La Vanguardia. ${ }^{47}$ Entre los jefes de redacción, así como en el resto del plantel, se podía reconocer una presencia importante de universitarios, maestros, escritores y periodistas, pero también de pintores, tipógrafos, torneros, carpinteros y zapateros. $^{48}$

\footnotetext{
${ }^{44}$ Enrico Ferri, "Trabajo intelectual y trabajo mecánico", La Vanguardia, 1 de junio de 1895, 1; Emile Vandervelde, "El Capitalismo y el trabajo intelectual", La Vanguardia, 12 de mayo de 1894, 1; "El proletariado intelectual", La Vanguardia, 22 de junio de 1895, 1; “Otra aclaración: los burgueses y los intelectuales dentro del partido", La Vanguardia, 19 de junio de 1897, 1-2.

${ }^{45}$ Un expoliado, "El bufón moderno", La Vanguardia, 28 de julio de 1894, 1.

46 Si bien las firmas femeninas no estuvieron ausentes en La Vanguardia, se trataba siempre de colaboraciones esporádicas ya que ninguna de las militantes socialistas de aquel entonces fue escogida por los miembros del partido para desempeñar un rol estable en la redacción del periódico. Con todo, la presencia femenina en las páginas de La Vanguardia no fue nada desdeñable y dio lugar a un arco variado de intervenciones de estilos muy diferentes. Una de las militantes más destacadas y con mayor presencia en las páginas de La Vanguardia fue Gabriela Laperrière, quien además de formar parte del Comité Ejecutivo, participó en forma muy activa en las discusiones desencadenadas en 1904 y 1905 a raíz del surgimiento de la tendencia sindicalista al interior del partido, corriente de la que ella fue una de las principales impulsoras. En el otro extremo, se puede encontrar esta presencia en funciones más acotadas y anexas, como la de Sara Justo, hermana de Juan Bautista, quien se encargó de traducir un texto de Jules Destree titulado "Los deberes de la mujer socialista", La Vanguardia, 22 de octubre de 1898, 2.

${ }^{47}$ Sobre la composición socio profesional del Partido Socialista en las primeras décadas del siglo XX, puede consultarse: Sergio Berensztein, Un partido para la Argentina moderna. Organización e identidad del Partido Socialista (1896-1916), Buenos Aires, Documentos CEDES/60, 1991, 19-23; y Richard Walter, The Socialist Party of Argentina 1890-1930, Austin, The University of Texas, 1979, 174-176.

${ }^{48}$ En el primer grupo figuran Juan B. Justo, Enrique Dickmann, Nicolás Repetto, Augusto Bunge, José Ingenieros, Nicanor Sarmiento, Julio Arraga, Mauricio Kliman, Benardo Irurzún, Manuel Meyer González, Guido A. Cartei, Alfredo J. Torcelli, y en el segundo Augusto Kühn, Esteban Jiménez, Luis Bernard, Adrián Patroni, Alfredo Pasqualetti, Eneas Arienti, Domingo Risso, Juan Schaeffer.
} 
Respecto al vínculo que los redactores de La Vanguardia establecieron con la labor periodística, resulta significativo señalar que hubo quienes desarrollaron esa actividad -tan denostada al nivel del discurso- como era la de escribir para periódicos "burgueses". En efecto, si en el plano de las representaciones había una gran distancia entre el militante que se sacrificaba por la "causa" y el escritor que vendía sus servicios al mejor postor, en el nivel de las prácticas, resultaba más difícil escindir ambas esferas. Esta aparente contradicción es analizada en el siguiente apartado a partir de las trayectorias de algunos militantes socialistas representativos.

\section{Trayectorias}

De los veintiocho redactores de La Vanguardia nombrados entre 1894 y 1905, tan sólo uno se reconocía a sí mismo y era reconocido por los demás como un periodista. Se trataba de Alfredo J. Torcelli (1864-1936), de quien apenas se conocen algunos pocos datos biográficos. Con un inicio muy precoz en el terreno periodístico, a los veintún años de edad dirigió El Pensamiento, semanario literario "dedicado al bello sexo", publicado en la ciudad de Buenos Aires. ${ }^{49}$ Ya afiliado al socialismo trabajó en La Provincia, diario de La Plata, fue fundador del Círculo de Periodistas de la Provincia de Buenos Aires en 1908 y editó las obras de Almafuerte y Florentino Ameghino, de quien además escribió una biografía. ${ }^{50}$ Entre 1903 y 1904 Torcelli fue jefe de redacción de La Vanguardia, período durante el cual expresó las dificultades para conciliar dos formas muy diferentes de relacionarse con el periodismo: como profesión que debía reportarle un sostén económico y como práctica militante destinada a difundir el socialismo. En más de una ocasión se refirió a los problemas financieros a los que debía hacer frente: en carta a José Ingenieros habló de la "bárbara miseria en que vivo desde hace dos años" y en un artículo publicado en La Vanguardia se definió como un "muerto de hambre". ${ }^{51} \mathrm{El}$ cargo de redactor en jefe le reportaba un ingreso de entre 40 y 50 pesos al mes (lo mismo que percibía un agente de policía), además de algunas acusaciones por ejercer sus tareas en forma autoritaria, frente a las cuales Torcelli ironizaba aludiendo al auge de popularidad que había alcanzado en su "remuneradísimo y apacible cargo de Redactor de La Vanguardia". ${ }^{2}$ En 1905, además, fue escogido como secretario de redacción del órgano partidario en su nueva etapa de diario de la mañana, pero la polémica que entabló ese mismo año con el Comité Ejecutivo (relacionada con su cercanía a algunos miembros del sector "sindicalista") explica por qué finalmente ese puesto recayó en Esteban Jiménez. ${ }^{53}$

\footnotetext{
49 Alberto Navarro Viola, Anuario Bibliográfico de la República Arjentina. Año VII-1885, Buenos Aires, Imp. de M. Biedma, 1886, 382.

${ }^{50}$ Carta de Alfredo J. Torcelli a José Ingenieros, 25 de septiembre de 1905, Fondo José Ingenieros, CeDInCI, A-6-1; Horacio Tarcus (dir.), Diccionario biográfico de la izquierda argentina. De los anarquistas a la "nueva izquierda", 18701976, Buenos Aires, Emecé, 2007, 653.

${ }^{51}$ Carta de Alfredo J. Torcelli a José Ingenieros, 12 de noviembre de 1903, Fondo José Ingenieros, CeDInCI, A-6-1 y Alfredo J. Torcelli, "Por la verdad", La Vanguardia, 5 de diciembre de 1903, 2.

52 Alfredo J. Torcelli, "Siempre cuestiones personales!", La Vanguardia, 6 de febrero de 1904, 4.

53 "Movimiento socialista", La Vanguardia, 13 de mayo de 1905, 3; "Movimiento socialista", La Vanguardia, 24 de junio de 1905, 3; Alfredo J. Torcelli, "Una carta”, La Vanguardia, 1 de julio de 1905, 2.
} 
Con todo, son las trayectorias de Juan B. Justo y Adrián Patroni aquellas que ilustran mejor que ninguna otra los complejos vínculos que los socialistas entablaron con la actividad periodística. Con perfiles socioprofesionales y estilos de militancia muy diferentes, Justo y Patroni fueron probablemente los dirigentes más destacados del socialismo de este período. Dado que, además, ambas figuras se desempeñaron con cierta visibilidad en los "grandes diarios" de Buenos Aires, el repaso por sus itinerarios permite dar cuenta con mayor precisión y matiz del lugar que ocupó la práctica periodística en las estrategias de intervención política del socialismo en el cambio de siglo.

Juan B. Justo (1865-1928), nacido en Buenos Aires en el seno de una familia de comerciantes y hacendados medios, con orígenes criollos e italianos, gozó de una educación formal, primero en el Colegio Nacional, y luego en la Facultad de Medicina de la Universidad de Buenos Aires. ${ }^{54}$ La necesidad de complementar sus ingresos mientras cursaba sus estudios universitarios lo condujo a tener su bautismo en la actividad periodística al emplearse como cronista parlamentario de La Prensa; transcurrían los primeros años de la década del ochenta y Justo tomaba un primer contacto directo con las instituciones de la república asistiendo a los debates por las leyes "laicas" en el Congreso. Colaboró en la revolución de 1890 en carácter de médico, socorriendo a los heridos, pero rápidamente se alejó de la Unión Cívica, agrupación que promovió el levantamiento. En los años siguientes, a la par que ejerció su profesión de médico, comenzó a estudiar las obras de Marx y a vincularse con los periódicos y círculos obreros y socialistas de Buenos Aires. Tras la puesta en marcha de La Vanguardia en 1894, Justo emergió como uno de los principales impulsores de la institucionalización política del movimiento socialista, al participar de todas las instancias fundacionales del partido. Durante su viaje de 1895, entabló relación con dirigentes socialistas de Francia, Bélgica y España. Por esos años, además, emprendió la traducción del alemán del tomo primero de El Capital, dictó conferencias (algunas de ellas editadas luego como folletos), y fue el impulsor de diversas instituciones obreras y socialistas, como la Cooperativa de Publicaciones, la Sociedad Obrera de Socorros Mutuos y la Sociedad Luz.

En relación a su labor periodística, sus principales esfuerzos estuvieron dedicados a La Vanguardia. En la reunión en el café de la calle Esmeralda de agosto de 1893, Justo puso a disposición dinero personal para financiar un periódico que abogara por la centralización partidaria del emergente movimiento socialista y, en el mismo acto, se hizo cargo de la dirección ideológica y política del semanario. Le dio un título, escribió su primer editorialpresentación y se hizo cargo en forma permanente de su redacción. Desde ese momento, y hasta su muerte en 1928, Justo ejerció un magisterio político e intelectual indiscutible en La Vanguardia. Sin embargo, incluso en los primeros años, difícilmente puede hablarse de $L a$ Vanguardia como el "periódico de Justo", del mismo modo en que en que los historiadores del socialismo francés suelen referirse a l'Humanité como el "periódico de Jaurès". ${ }^{5}$ Desde

\footnotetext{
${ }^{54}$ Cúneo, op. cit.; Pan, op. cit.; Tarcus (dir.), op. cit., 326-332.

55 Alexandre Courban, l'Humanité de Jean Jaurès à Marcel Cachin (1904-1939), Yvry-sur-Seine, Les editions de l'Atelier, 2015, 25-76; Madeleine Rebérioux, "Le journal de Jaurès", Christian Delporte, Claude Pennetier, Jean-François Sirinelli et al (dirs.), op. cit., 19-42; Charles Silvestre, Jaurès, la passion du journaliste, Paris, Le Temps des Cerises, 2010, 51-66.
} 
el punto de vista material y organizativo, ya fue mencionado que tras celebrarse el Congreso Constituyente del Partido Socialista en 1896, la evolución financiera del periódico adquirió autonomía de las contribuciones personales. Así, cuando en 1899 Justo propuso la transformación de La Vanguardia en diario matutino, ofreciendo diez mil pesos de sus propios ahorros, el Comité Ejecutivo del Partido rechazó la donación. ${ }^{56}$ Desde el punto de vista doctrinario, la recepción del "socialismo científico" en clave evolucionista y objetivista que impulsó Justo no constituyó el único registro ideológico y discursivo que podía encontrarse en las páginas del semanario, ya que compartía espacio con una veta romántica y revolucionaria explotada por otras plumas frecuentes, como las de Adrián Patroni, Carlos Mauli, Esteban Jiménez, Domingo Risso y Augusto Kühn. ${ }^{57} \mathrm{Y}$ en relación a su papel en la dirección política y editorial de La Vanguardia, aunque no se puede desestimar la influencia indirecta que ejerció como líder de una tendencia que buscaba hegemonizar la orientación estratégica del partido, hay que señalar que Justo no estuvo a cargo siempre, ni la mayor parte del tiempo, de la toma de decisiones al interior de la redacción. ${ }^{58}$

Además de su participación en La Vanguardia, hubo otras facetas menos conocidas de la trayectoria de Justo en la actividad periodística que merecen ser destacadas. A mediados de 1896, momento clave de la consolidación organizativa del Partido Socialista, Justo ingresó por un período de tres meses en la redacción de La Nación. Este matutino fundado por Bartolomé Mitre en 1870 ocupaba el segundo lugar en tirada de la ciudad y hacía circular 58.000 ejemplares diarios en $1898 .{ }^{59}$ Las colaboraciones de destacados escritores nacionales y extranjeros hacían de este diario un espacio fundamental de la modernización literaria, aunque ello se combinaba con el despliegue de funciones político-partidarias relacionadas a su vínculo orgánico con el mitrismo. ${ }^{60}$

Desde la columna de movimiento obrero de La Nación, Justo informó sobre las actividades de los grupos socialistas de Buenos Aires, en particular, las alternativas del Congreso Constituyente del Partido Socialista de fines de junio. También escribió numerosos artículos - muchos de los cuales ocuparon el lugar del editorial-, que abordaban cuestiones como la situación de los inmigrantes, el papel del capital inglés en el país, la política

\footnotetext{
56 "Movimiento Socialista. Comité Ejecutivo", La Vanguardia, 3 de junio de 1899, 3.

${ }^{57}$ Tarcus, op. cit., 314-315.

${ }^{58} \mathrm{Si}$ bien la prédica de Justo desde las páginas de La Vanguardia había sido fundamental para concretar la centralización partidaria, en el transcurso del Congreso Constituyente de 1896 sus posiciones en algunos aspectos claves -como su apertura a las alianzas políticas con otras fuerzas o su oposición al recurso de la violencia- fueron derrotadas. $L a$ Vanguardia, en su nuevo carácter de órgano oficial del nuevo partido, reflejó esta correlación de fuerzas: el jefe de redacción surgido del Congreso de 1896 fue Adrián Patroni, uno de los delegados que había sostenido mociones contrarias a las defendidas por Justo (quien ni siquiera fue elegido para componer el staff de cinco redactores estables). No obstante, el joven médico volvió a ingresar al año siguiente a la redacción de La Vanguardia, elegido por voto general, mientras que José Ingenieros y Leopoldo Lugones, los principales agitadores de las posturas contrarias, crearon su propio semanario titulado La Montaña. Luego de renunciar en 1899 a su puesto en La Vanguardia, Justo no volvió a dirigirla ni formó parte estable de su redacción sino hasta 1905, cuando el órgano partidario comenzó a salir como diario matutino.

${ }^{59}$ Angelo De Gubernatis, "La stampa argentina”, L'Argentina: ricordi e letture, Firenze, Bernardo Seeber, 1898, $323-342$.

${ }^{60}$ Julio Ramos, Desencuentros de la modernidad en América Latina, El Perro y la Rana, Caracas, 2009, 184-199; Eduardo Zimmermann, "La prensa y la oposición política en la Argentina de comienzos de siglo: el caso de La Nación y el Partido Republicano”, Estudios Sociales, № 15, 1997, 45-70.
} 
económica, la organización política de los trabajadores y la doctrina socialista. ${ }^{61}$ Justo no firmaba sus artículos, pero no se privaba de dar profesión de su fe en el socialismo. ${ }^{62}$ No obstante, a fines de agosto, Justo presentó su renuncia, disconforme por las críticas que en otras secciones del diario se realizaba a la huelga ferroviaria que se desarrollaba en ese momento. ${ }^{63}$ Este repentino alejamiento fundado en razones político-ideológicas nos previene de considerar su acercamiento inicial a La Nación como el producto de una búsqueda de sostén económico en la actividad periodística. En realidad, excepto por sus años de estudiante, Justo nunca vivió del periodismo. Todo lo contrario, fue su exitosa carrera de médico la que le permitió financiar proyectos periodísticos militantes.

La actuación de Justo en uno de los principales representantes de la defenestrada "prensa burguesa" debe pensarse en vinculación a otro tipo de factores. Uno de ellos remite a la sensibilidad ideológica compartida entre el socialismo parlamentarista de Justo y el reformismo liberal que profesaba el diario fundado por Bartolomé Mitre, en función de la cual coincidían en algunos puntos generales relativos a la defensa del librecambio, a su posicionamiento respecto a la cuestión social y a sus reclamos por la libertad del sufragio. Asimismo, el diario de Mitre constituía un espacio de reunión fundamental para el universo de la bohemia artística y literaria de la Buenos Aires del noventa, muchos de cuyos miembros también participaban en forma activa en los primeros pasos del socialismo. Por otra parte, si tenemos en cuenta que a fines de junio Justo sufrió una derrota parcial en el Congreso Constituyente del socialismo, que significó su desplazamiento de su lugar rector en La Vanguardia, su llegada a La Nación podría interpretarse como una búsqueda por hacerse de una caja de resonancia alternativa de sus posiciones en la prensa. Sobre todo, si se recuerda que, lejos de ser un diario leído solo por las élites, La Nación llegaba cotidianamente a un conjunto amplio y socialmente heterogéneo de lectores, en parte compartido con el público al que aspiraba La Vanguardia.

La conciencia e, incluso, la atracción que sentía Justo respecto de la capacidad de los "grandes diarios" modernos como La Nación para ocupar un lugar central en la sociedad, en la política y en la cultura de su tiempo se confirman al observar las características de $E l$ Diario del Pueblo, el proyecto periodístico que lanzó a título propio a fines de 1899. En los meses previos, Justo había intentado sin éxito convencer al Comité Ejecutivo del partido de llevar adelante la transformación de La Vanguardia en diario. ${ }^{64}$ Ante la negativa, se embarcó en el proyecto en forma personal, acompañado por otros socialistas, como Augusto Kühn, Domingo Risso, Nicolás Repetto y Julio A. Arraga. ${ }^{65} \mathrm{Si}$ bien Justo lo definía como un "diario político", El Diario del Pueblo no mantenía un vínculo orgánico con el Partido Socialista ni se refería explícitamente al socialismo. ${ }^{66}$ Con todo, defendía las mismas ideas que La Vanguardia. ${ }^{67}$

\footnotetext{
${ }^{61}$ Juan B. Justo, Labor periodística, Buenos Aires, Ediciones mínimas, 1916.

62 "El Socialismo y Max Nordau”, La Nación, 27 de julio de 1896, 3

63 "La huelga monstruo", La Vanguardia, 29 de agosto de 1896, 2.

64 "Movimiento Socialista. Comité Ejecutivo", La Vanguardia, 3 de junio de 1899, 3; Cúneo, op. cit., 202.

${ }^{65}$ Nicolás Repetto, Mi paso por la política. De Roca a Yrigoyen, Buenos Aires, Santiago Rueda, 1956, $23-27$.

${ }^{66}$ En un suelto Justo afirmaba: "éste es, ante todo, un diario político, que ha venido a condenar todo lo falso y perverso que hay en la vida pública del país, y señalar los medios de corregirlo. Pero no responde absolutamente a propósitos electorales de partido alguno, ni mucho menos de personas. Por su parte, el director de El Diario del Pueblo no aceptará
} 
El Diario del Pueblo se propuso desde el comienzo llamar la atención de los "grandes diarios". Su intención era ingresar de lleno en los debates que agitaban a una opinión pública periodística poderosa e influyente, en una coyuntura en la que la denominada "prensa independiente" constituía un verdadero foco de oposición al oficialismo y que influía en forma determinante respecto a lo que se sabía y discutía sobre la cuestión social y la cuestión obrera. Justo estaba al tanto del poder de la "gran prensa" y escribió, ya en la primera semana de aparición de El Diario del Pueblo, un editorial titulado "La culpa de la prensa en los vicios de la política", donde decía: "Hay la más estrecha relación entre la vida electoral y administrativa de un país y el estado de la opinión pública, y ésta se forma y se manifiesta en la prensa diaria. En una sociedad moderna, por consiguiente, si la vida política es viciosa, sus vicios provienen en gran parte de la prensa, y en ella se reflejan". ${ }^{68}$

Este intento por ser reconocido en la arena periodística no fue del todo fracasado, ya que logró un sostenido intercambio polémico con los periódicos, muy poderosos y de amplísima tirada, de la comunidad italiana: La Patria degli Italiani y l'Italia al Plata ${ }^{69}$ Por supuesto, la disputa tenía que ver con el bajísimo índice de adquisición de los derechos políticos por parte de los inmigrantes italianos en la Argentina: Justo estaba convencido de que uno de los factores que lo explicaban era el "necio orgullo patriótico, negativo y estéril" fomentado por la prensa étnica. ${ }^{70} \mathrm{En}$ el marco de la polémica, los instrumentos retóricos de Justo eran variados, de cara a sostener una interpelación amplia y accesible al heterogéneo público metropolitano. Así, escribía que "puede uno comer puchero y tomar mate sin perder la afición a la cerveza, a los tallarines o a los garbanzos", para afirmar que un europeo podía mostrar un interés activo por la vida política del país donde paga impuestos, sin dejar de recordar y amar el otro país donde ha nacido y vivido. ${ }^{71}$

Esta búsqueda de ampliar la interpelación expresa la peculiaridad de este periódico dentro del campo socialista: si bien mantenía una postura muy crítica del "campo periodístico" y, en particular, de "los redactores de diarios", El Diario del Pueblo adaptaba ciertas modalidades de la "gran prensa" con la esperanza de que los nuevos lectores sustituyeran la lectura de dichos órganos para mantenerse informados. Ofrecido a cinco centavos en kioscos, almacenes, peluquerías y cafés, se presentaba en gran formato, con seis columnas que contenían los servicios informativos usuales de la "gran prensa" porteña: telegramas internacionales, crónica parlamentaria, policiales, bolsa de comercio, justicia, noticias de

candidatura alguna, aun cuando fuera la de un grupo o partido político con programa". "Declaración", El Diario del Pueblo, 7 de noviembre de 1899, 1.

${ }^{67}$ En su primera editorial, El Diario del Pueblo hacía explícito su programa: “Combatirá la política criolla de la oligarquía inepta y rapaz que pesa sobre el país. Defenderá al pueblo trabajador de las ciudades y del campo. Estará contra los avances del estado, contra el parasitismo político de las provincias que no se bastan a sí mismas, contra la tiranía de las empresas extranjeras que monopolizan las grandes vías públicas, contra la prensa mercenaria. Sostendrá una política exterior de comercio libre y pacífico, la democratización de las instituciones militares, la entrada de la población extranjera en la política nacional, y la igualdad de todas las creencias ante la ley. "El Diario del Pueblo", El Diario del Pueblo, 1 de octubre de 1899, 1.

68 "La culpa de la prensa en los vicios de la política", El Diario del Pueblo, 7 de octubre de 1899, 1.

${ }^{69}$ Federica Bertagna, La stampa italiana in Argentina. Roma, Donzelli, 2009, 25-48.

70 "Nuevas prácticas y no nuevas leyes", El Diario del Pueblo, 22 de octubre de 1899, 1.

71 "Sobre el mismo tema", El Diario del Pueblo, 27 de octubre de 1899, 1. 
última hora, municipales, vapores, deportes, teatro, espectáculos, incluso carreras. En su fisonomía predominaban las noticias breves relatadas en tono objetivo y sintético, donde "las discusiones doctrinarias, embebidas en el más pretencioso trascendentalismo, esta[ba]n desterradas en absoluto". ${ }^{72} \mathrm{Su}$ interpelación era amplia y se dirigía al "pueblo trabajador", aunque su objetivo apuntaba a los sectores más prósperos y educados de la clase trabajadora y a los cada vez más numerosos sectores medios, como estudiantes, profesionales, incluso chacareros del litoral pampeano. El lector delineado en sus páginas podía desvelarse por los cables sobre la guerra Anglo-bóer, encolerizase con los engaños de la "oligarquía inepta y rapaz", informarse sobre las novedades del teatro y las carreras, seguir la cotización de oro y de los precios agrícolas, y entusiasmarse con el aviso del Banco "El Hogar Argentino" que lo tentaba con la posibilidad de dejar de pagar un alquiler y convertirse en dueño de una vivienda autoconstruida.

Pero esta ambiciosa apuesta de Justo por encontrar un lugar en el terreno de la "gran prensa" matutina, combinando un discurso programático y combativo con una estrategia comercial adaptada al público masivo, no prosperó. Al mes de su aparición, los redactores de La Vanguardia admitieron que muchos trabajadores aún ignoraban que existía un diario que se proponía defender sus intereses. ${ }^{73}$ Cuando estaban por cumplirse dos meses de su aparición, El Diario del Pueblo se despidió de sus lectores. En el último editorial, Justo destacaba las dificultades desde el punto de vista mercantil que enfrentaba un diario que pretendiera defender al pueblo trabajador ("si un diario como éste fuera negocio -nos ha dicho alguien- otros ya lo habrían hecho") pero dejaba la puerta abierta para que dicha empresa, por dura que fuese, pudiera conseguirse en el futuro: "porque no hayamos conseguido realizarla, no vamos, sin embargo, a considerarla imposible. Bienvenido sea el que haga un negocio de esta obra inteligente y buena". ${ }^{74}$ Por lo pronto, Justo dejó inmediatamente la ciudad y se instaló en la localidad de Junín, donde residió durante más de un año estudiando la "cuestión agraria" argentina. Desde allí, envió colaboraciones esporádicas al diario El Tiempo, vespertino que, a pesar de ser un integrante de los periódicos "burgueses", era reconocido por los redactores de La Vanguardia por ser "entre los diarios argentinos [...] uno de los que está escrito en un tono más liberal y progresista" ${ }^{75}$ En sus páginas escribían, de hecho, más de un socialista, entre ellos Adrián Patroni, uno de los militantes más activos y representativos de aquellos años.

Nacido en Montevideo y de padres italianos, Adrián A. Patroni (1867-1950) tuvo su primer contacto con el mundo de la prensa periódica de pequeño, al trabajar como canillita en las calles de su ciudad natal. ${ }^{76}$ Trasladado a Buenos Aires, trabajó de pintor por cuenta propia,

\footnotetext{
72 José Ingenieros, "El Diario del Pueblo", La Vanguardia, 7 de octubre de 1899, 1

${ }^{73}$ Esteban Dagnino, "El Diario del Pueblo", La Vanguardia, 9 de diciembre de 1899, 2.

74 “Redacción. El Diario del Pueblo", El Diario del Pueblo, 30 de noviembre de 1899, 1.

75 "El Tiempo, los radicales y los clérigos", La Vanguardia, 16 de junio de 1895, 1. Juan B. Justo, "Los nuevos problemas", El Tiempo, 19 de julio de 1900, 1; Juan B. Justo, "La contribución directa”, El Tiempo, 25 de julio de 1900, 1; Juan B. Justo, "La buena solidaridad”, El Tiempo, 11 de agosto de 1900, 1.

${ }^{76}$ Adrián Patroni, Más corazón que cerebro, Buenos Aires, Buenos Aires, L. Rosso y Cía., 1924; Víctor García Costa, Adrián Patroni y la situación de los trabajadores en la Argentina, Buenos Aires, Docencia, 2011, 25-129; Cristóbal Maro, "Adrián Patroni. Aproximación biográfica de un trabajador socialista a fines del siglo XIX", XI Jornadas Interescuelas/Departamentos de Historia, Tucumán, 2007.
} 
y desde fines de la década del ochenta comenzó a frecuentar los cafés donde transcurría la sociabilidad de los círculos obreros y socialistas. Se afilió a la Sociedad de Resistencia de los Obreros Pintores y luego a la Agrupación Socialista de Buenos Aires. Se dedicó entonces al estudio de las ideas socialistas a través de los folletos y periódicos que empezaban a circular con mayor asiduidad. Patroni escribió en La Vanguardia desde el primer año de su publicación, fue nombrado cuatro veces jefe de redacción durante su período como semanario y a mediados de 1895 ejerció como su administrador. Hasta su alejamiento del socialismo a mediados de la primera década del nuevo siglo, llevó adelante una labor incansable como propagandista: además de su actividad en La Vanguardia, participó de todas las instancias fundacionales del Partido Socialista, dictó conferencias, lideró huelgas, organizó mitines, realizó giras de propaganda por el interior, escribió y editó sus propios folletos y publicó sus propios periódicos.

Al frente de la redacción de La Vanguardia a mediados de 1896, Patroni impulsó un enfoque pedagógico y popular que empleaba recursos de propaganda tales como los diálogos y correspondencias de ficción, las canciones, los poemas y las ilustraciones. Convencido de que debían hallarse modos de divulgar "doctrinas demasiado científicas para ser comprendidas por una clase trabajadora en su mayor parte bastante atrasada", impulsó la utilización de un lenguaje "vulgarísimo" para captar a los "indiferentes". ${ }^{77}$ Los diálogos de ficción fueron una de las herramientas preferidas: escritos en un lenguaje cercano a la oralidad, pretendía mostrar hechos de la vida social de los trabajadores explicados desde el punto de vista socialista. En algunos casos, se trata de intercambios de cierta extensión, cuyo objeto central es exponer en forma sencilla y accesible algunos fundamentos históricos y teóricos de la pertinencia de las ideas socialistas. ${ }^{78}$ En otros casos, se ofrecen pequeñas viñetas literarias que buscan representar en forma realista la situación de los trabajadores, o bien configurar estereotipos de las actitudes y valores de los miembros de las clases privilegiadas. ${ }^{79}$ Otros recursos introducidos por Patroni en $L a$ Vanguardia fueron los tópicos y figuras del criollismo popular. Buscando aprovechar la enorme difusión que tenían las novelas y poemas protagonizados por gauchos por medio de la prensa periódica y de folletos vendidos a bajo precio, este militante socialista adoptó muchos de sus elementos a las necesidades de la propaganda socialista. De este modo, no sólo se buscaba establecer un puente con la sensibilidad de los trabajadores rurales quienes, según varios dirigentes, no eran tenidos en cuenta en el mensaje socialista-, sino

\footnotetext{
77 Adrián Patroni, “A los miembros del Partido Socialista”, La Vanguardia, 9 de agosto de 1902, 1; Adrián Patroni, “A los indiferentes", La Vanguardia, 4 de diciembre de 1897, 2; "Carta abierta a un obrero indiferente", La Vanguardia, 8 de diciembre de 1897, 1-2; "Estaba ebrio...! A los indiferentes", La Vanguardia, 11 de diciembre de 1897, 2; "A los indiferentes", La Vanguardia, 25 de marzo de 1899, 4. Sobre esta faceta de la militancia de Patroni, puede consultarse: Lucas Poy, "«Despertar al pueblo trabajador». Los diálogos de Adrián Patroni en La Vanguardia y en el $A B C$ del Socialismo (1896-1900)", Estudios del Trabajo No 49/50, 2015, 133-153.

78 Por ejemplo: Adrián Patroni, "Lucha de clases", La Vanguardia, 14 de noviembre de 1896, 3; Adrián Patroni, "Pequeña cartilla socialista", La Vanguardia, 15 de octubre de 1898, 2; Inotrap, "Cooperativa de consumo", La Vanguardia, 22 de octubre de 1898, 1.

79 Por ejemplo: Adrián Patroni, "Cinematógrafos de actualidad”, La Vanguardia, 20 de noviembre de 1897, 2; Adrián Patroni, "Cinematógrafos de actualidad", La Vanguardia, 3 de diciembre de 1898, 1.
} 
que también se pretendía ofrecer contenidos atractivos para lograr una mayor integración a la cultura local de los inmigrantes afincados en las grandes ciudades. ${ }^{80}$

A partir del $1^{\circ}$ de septiembre de 1899, Patroni lanzó el $A B C$ del Socialismo, "periódico semanal de propaganda popular", donde puso en práctica muchos de los recursos mencionados. Publicado en formato pequeño y a dos columnas, su apuesta fue ofrecer a los militantes una hoja útil para hacer propaganda entre los trabajadores que aún no sabían qué era el socialismo. ${ }^{81}$ El bajísimo precio del periódico - un centavo el ejemplar- se relacionaba con la idea que tenía Patroni de que los centros y cada uno de los militantes socialistas debían suscribirse al $A B C$ del Socialismo, para luego hacerlo circular en forma gratuita entre la población trabajadora. Además de los diálogos de ficción y el empleo de tópicos criollistas, Patroni implementó allí el "Alfabeto Socialista": siguiendo la idea contenida en el título del periódico, que llamaba a completar la alfabetización de las masas populares acercándoles las ideas socialistas, en cada número se incluía una reflexión o una definición por cada letra del abecedario.

Resulta interesante notar algunas diferencias entre el $A B C$ del Socialismo y El Diario del Pueblo, sobre todo si se tiene en cuenta que fueron publicados al mismo tiempo. Por una parte, estos periódicos otorgaban un lugar muy diferente al socialismo dentro de su discurso. Si el diario de Justo evitaba utilizar en forma explícita el discurso doctrinario y elegía en cambio un lenguaje "objetivo", a tono con el periodismo moderno, la apuesta del semanario de Patroni era, justamente, difundir en un registro sencillo y accesible el conjunto de ideas que conformaban la doctrina socialista. En este sentido, los títulos de los periódicos eran transparentes de aquello que querían mostrar y/o ocultar. Por otra parte, construían una imagen algo diferente de sus lectores. Si bien ambos decían estar dirigidos al "pueblo trabajador", el diario de Justo apuntaba a los sectores más acomodados de la clase trabajadora y a los emergentes sectores medios urbanos y rurales, mientras que el lector imaginado del $A B C$ del Socialismo era un trabajador manual de la ciudad o un peón de campo, criollo o inmigrante, con escasas habilidades lectoras y que era víctima de la explotación, la inestabilidad laboral y los abusos patronales.

Si bien La Vanguardia había incorporado a sus páginas el tipo de materiales que ofrecía el $A B C$ del Socialismo, no veía en él un competidor sino un complemento. Redactado por uno de los militantes más importantes del partido, este periódico permitía, dado su bajísimo precio, llegar a lugares donde el órgano partidario no podía llegar, por venderse a un valor cinco o diez veces más alto. El propio Comité Ejecutivo, incluso, solía suscribir miles de

\footnotetext{
${ }^{80}$ Manuel Meyer González, "El socialismo y el proletariado rural”, La Vanguardia, 18 de julio de 1896, 1; Enrique Dickmann, "Los trabajadores de la campaña (del interior)", La Vanguardia, 19 de febrero de 1898, 1; Enrique Dickmann, "Los trabajadores del campo", La Vanguardia, 11 de mayo de 1901, 2-3; Adrián Patroni”, Los trabajadores del campo", La Vanguardia, 7 de diciembre de 1901, 1; Bernardo Irurzún, “Cómo llevar la propaganda socialista a la campaña argentina?", La Vanguardia, 1 de febrero de 1902, 2; Adrián Patroni, "Un episodio de propaganda. Cómo despiertan a los criollos", La Vanguardia, 21 de junio de 1902, 2; Adrián Patroni, "A los miembros del Partido Socialista", La Vanguardia, 9 de agosto de 1902, 1. Sobre el criollismo popular: Prieto, op. cit.

81 “A los socialistas", ABC del Socialismo, 1 de septiembre de 1899, 1.
} 
copias del $A B C$ del Socialismo para repartir entre los asistentes de actos, fiestas y manifestaciones organizadas por el partido. ${ }^{82}$

Con el tiempo, no obstante, la relación de solidaridad entre La Vanguardia y el periódico de Patroni iba a encontrar su límite. Extinto El Diario del Pueblo, Patroni lanzó a principios de 1900 el proyecto de transformación del ABC del Socialismo en un diario de mayor formato y "con todas las informaciones que tienen los grandes diarios". ${ }^{83}$ Para ello, preveía cambiar el nombre del periódico por La Idea, buscando así "evitar que una parte del público lo rechace atemorizado por la palabra socialismo". ${ }^{84} \mathrm{El}$ cambio, sin embargo, no se efectuó, probablemente por haber fracasado la campaña para obtener listas de suscriptores. En agosto de 1901, Patroni volvió a insistir con un proyecto parecido y el $A B C$ del Socialismo fue finalmente reemplazado por un nuevo periódico, titulado El Trabajo, que aparecía los sábados y domingos. A diferencia de su predecesor, este periódico se vendía en las calles y en los kioscos, y no utilizaba la palabra socialismo en su título. Su lanzamiento fue acompañado además con el intento de constituir una sociedad cooperativa de cara a su transformación en diario. ${ }^{85} \mathrm{El}$ deseo de Patroni por ocupar el espacio diario que había dejado El Diario del Pueblo pareció realizarse a principios de 1902, cuando anunció la aparición de La Agitación, diario de la tarde. Pero el objetivo de tener su propio diario socialista no se concretó por la oposición de su propio partido, interesado en esos momentos por maximizar los recursos de cara a una transformación de La Vanguardia en diario -que se concretaría en 1905-. Ante el pedido del Comité Ejecutivo para que desistiera del proyecto, Patroni aceptó sin demoras. ${ }^{86}$

La conciencia de Justo respecto del poder de los "grandes diarios" modernos para influir en la vida pública no era excepcional. Ella se podía hallar entre los miembros del Comité Ejecutivo comprometidos con la transformación de La Vanguardia, y en el propio Patroni, quien buscó redireccionar, como vimos, sus propios proyectos periodísticos hacia el modelo que exhibía la "gran prensa" de información. De hecho, a pesar de ser uno de los socialistas que más criticó a la "prensa mercantilista" y a sus "escritores a sueldo", Patroni desarrolló desde mediados de los años noventa una carrera de redactor estable en la "prensa burguesa". El más importante de estos trabajos fue el que realizó en el diario El Tiempo entre 1896 y 1902. Este vespertino fundado en 1894 y dirigido por Carlos Vega Belgrano, era el vocero del radicalismo identificado con Bernardo de Irigoyen, pero a la vez presentaba una oferta periodística moderna que, de modo similar a La Nación, combinaba el peso de la información internacional con el seguimiento de las novedades literarias. ${ }^{87}$ Muy vinculado a los círculos de escritores y artistas modernistas - Vega Belgrano era quien

\footnotetext{
${ }^{82}$ Por ejemplo: "Movimiento socialista", La Vanguardia, 16 de septiembre de1899, 3.

83 "Una grata noticia. El ABC del Socialismo convertido en diario", ABC del Socialismo, 25 de marzo de 1900, 1.

84 "La Idea", ABC del Socialismo, 1 de abril de 1900, 3.

85 "El Trabajo", La Vanguardia, 10 de agosto de 1901, 3

${ }^{86}$ Enrique Dickmann, "Nuestra prensa", La Vanguardia, 5 de abril de 1902, 3; Enrique Dickmann, "La necesidad de un diario", La Vanguardia, 12 de abril de 1902, 1; "Movimiento Socialista”, La Vanguardia, 10 de mayo de 1902, 1.

${ }^{87}$ Nahuel Ojeda Silva, El Tiempo: prensa y política durante la crisis de la Unión Cívica Radical (1896-1905), Tesis de Licenciatura, Universidad Torcuato Di Tella, 2012.
} 
financiaba las actividades del Ateneo que los nucleaba-, El Tiempo publicaba a Rubén Darío, Manuel Ugarte y al entonces socialista Leopoldo Lugones. ${ }^{88}$

Como redactor de El Tiempo, Patroni se hizo cargo de la sección del movimiento obrero, donde -al igual que Justo en La Nación- informaba sobre las actividades de los gremios y sociedades de resistencia, sobre el desarrollo de los principales conflictos laborales y sobre las distintas iniciativas relacionadas con el Partido Socialista. En un momento de auge huelguístico como la segunda mitad de 1896, la sección "Los obreros" fue reemplazada por una columna denominada "Las huelgas", en la que Patroni volcaba la información de las huelgas en las que él mismo era protagonista. En las páginas del diario L'Italia al Plata, la labor de repórter-huelguista de Patroni en El Tiempo era caracterizada de esta forma: "Alma, orador, repórter, distribuidor de manifiestos, propagandista infatigable, es el obrero Patroni, el cual va y viene de Buenos Aires a La Plata, con incansable rapidez". ${ }^{89}$

En El Tiempo, Patroni publicó, además, una serie de artículos sobre la situación de los trabajadores criollos, escritos tras algunos viajes por las provincias del interior, que sirvieron como plataforma para una campaña -desarrollada en las páginas de El Tiempo y de La Vanguardia - por la derogación de las leyes de vagancia y las libretas de conchabo en el norte argentino. Al año siguiente, estos artículos fueron reunidos en un folleto titulado $\mathrm{El}$ presente y el pasado del criollo. ${ }^{90}$ A pesar de que Patroni llevaba su práctica militante a las páginas de la "prensa burguesa", su presencia allí tuvo un fundamento económico y social antes que político. A diferencia de Justo, encontró en los "grandes diarios" un medio de vida e incluso una vía de ascenso social: su incorporación a la redacción de El Tiempo, sumada a algunas colaboraciones pagas que hizo para La Nación, le permitió abandonar la profesión de pintor antes de que el nuevo siglo comenzara. ${ }^{91} \mathrm{Y}$ ya en el contexto de su alejamiento de la actividad militante iniciado en 1904, ingresó como cronista de El Diario (vespertino de gran tirada, fustigado con frecuencia por La Vanguardia) hasta desembarcar en un cargo en el Ministerio de Agricultura, donde permaneció por casi veinte años. ${ }^{92}$

\section{Conclusión}

En estas líneas se buscó iluminar los rasgos singulares que asumieron las ideas y prácticas periodísticas en la militancia de los socialistas de la Buenos Aires de fines del siglo XIX. En un contexto marcado, en lo social, por el crecimiento económico, la movilidad social y la inmigración de masas y, en lo cultural, por la constitución de un mercado de bienes culturales facilitada por la modernización periodística, la voluntad de los dirigentes socialistas por llevar adelante la doble labor de organización política y concientización de las mayorías trabajadoras por medio de la prensa periódica conllevó importantes tensiones. En particular, se produjo un choque entre la tendencia a moldear el mundo del trabajo por

\footnotetext{
${ }^{88}$ Otro socialista cuyos cuya firma apareció en El Tiempo fue Antonino Piñero.

89 "El obrero Patroni", El Tiempo, 13 de agosto de 1896, 2.

${ }^{90}$ Adrián Patroni, El presente y pasado del criollo, Buenos Aires, Imp. La Popular, $2^{\text {a }}$ ed., 1897.

${ }^{91}$ Adrián Patroni, "Las cosas en su lugar", La Vanguardia, 19 de diciembre de 1903, 3.

92 Vicente Blasco Ibañez, Argentina y sus grandezas, Valencia, Prometeo, 1910, 419.
} 
vía de un liderazgo político centralizado y una cultura obrera y socialista relativamente autónoma, por un lado, y el amargo reconocimiento del papel que tenían los "grandes diarios" de Buenos Aires en la vida cotidiana del "pueblo trabajador", por el otro.

Una vía para observar estas tensiones fue suministrada por la historia del semanario La Vanguardia como espacio físico y discursivo de sociabilidad política. Desde su fundación, el periódico facilitó la institucionalización del socialismo argentino, en virtud de su capacidad para vincular los elementos dispersos del movimiento brindándoles información sobre reuniones y movilizaciones, así como también para apuntalar las definiciones estratégicas al interior del campo socialista mediante la difusión de materiales doctrinarios. No obstante, pronto sus animadores se vieron en la necesidad de captar la atención del emergente público lector de carácter masivo que aún se mantenía ajeno a las ideas socialistas. La fuerte referencialidad que tuvo el desarrollo del semanario en el estilo y en las modalidades de funcionamiento de la "gran prensa" de la ciudad, evidenció una forma de concebir la propaganda impresa relativamente flexible y permeable respecto al contexto específico en el cual debía desarrollarse.

La segunda vía para analizar el problemático despliegue de la militancia impresa de los socialistas fue ofrecida por el ejercicio de contraste entre las representaciones que formularon sobre el rol del periodista y sus trayectorias efectivas en el terreno periodístico. Si en el primer caso se pudo observar un corte tajante entre la exaltación del militante que realizaba en forma sacrificada múltiples tareas al interior de un periódico socialista y la condena del periodista especializado que trabajaba en la redacción de la "prensa burguesa" como un medio de vida, a nivel de las prácticas concretas ambas dimensiones se presentaron de forma mucho menos disociada. Las trayectorias periodísticas de Juan B. Justo y Adrián Patroni, aun cuando puedan pensarse como casos excepcionales respecto a la mayoría de los redactores de La Vanguardia, resultan de gran significación debido al papel principalísimo que ocuparon en la dirección y organización de la propaganda del socialismo a fines de siglo. Según se observó, el modo en que Justo y Patroni se vincularon con la actividad periodística tuvo importantes diferencias, aunque en ambos casos se pudo reconocer el mismo patrón de acción: el reconocimiento de las reglas de juego que establecía la modernización periodística y el aprovechamiento al máximo de las posibilidades que ella brindaba para conquistar a los nuevos lectores. Nuevamente, puede abonarse la imagen de una propaganda impresa, que lejos de agotarse en la construcción de una "subcultura" socialista, implicó el tendido de sólidos puentes con un contexto social y cultural tan lleno de constreñimientos como de oportunidades.

\section{Referencias}

\section{Fuentes primarias}

Libros, folletos, artículos

La Vanguardia 50 Aniversario, Buenos Aires, La Vanguardia, 1944. 
La Vanguardia. A 1 año de su clausura, Buenos Aires, Comisión de Prensa del Partido Socialista, 1948.

L'Organisation Corporative et la Presse Socialiste. Syndicat des Journalistes Socialistes et Chambre Syndicale des Journalistes, Paris, Libraire de la Revue Socialiste, 1893.

Ley de Jubilación de Periodistas, Buenos Aires, Publicaciones del Círculo de la Prensa, 1941.

Blasco Ibañez, Vicente, Argentina y sus grandezas, Valencia, Prometeo, 1910.

De Gubernatis, Angelo, L'Argentina: ricordi e letture, Firenze, Bernardo Seeber, 1898.

Dickmann, Enrique, Páginas Socialistas, Buenos Aires, La Vanguardia, 1928.

Justo, Juan B., Labor periodística, Buenos Aires, Ediciones mínimas, 1916.

Kühn, Augusto, "Apuntes para la historia del movimiento obrero socialista en la República Argentina", Políticas de la Memoria, $\mathrm{N}^{\circ}$ 5, 2004/2005, 136 [texto publicado originalmente en Nuevos Tiempos. Revista de Buenos Aires, entre el n ${ }^{\circ} 1,1 / 5 / 1916$ y el nº 7, 5/8/1916]

Longuet, Jean, "Le Parti Ouvrier Belge”, Adéodat Compère-Morel (Dir.), Encyclopèdie Socialiste, Syndicale et Cooperative de L'Internationale Ouvrière, Paris, Aristide Quillet, 1913.

Navarro Viola, Alberto, Anuario Bibliográfico de la República Arjentina. Año VII-1885, Buenos Aires, Imp. de M. Biedma, 1886.

Oddone, Jacinto, Historia del socialismo argentino, Buenos Aires, CEAL, 1983.

Patroni, Adrián, Más corazón que cerebro, Buenos Aires, Buenos Aires, L. Rosso y Cía., 1924.

Patroni, Adrián, El presente y pasado del criollo, Buenos Aires, Imp. La Popular, $2^{a}$ ed., 1897.

Repetto, Nicolás, Mi paso por la política. De Roca a Yrigoyen, Buenos Aires, S. Rueda, 1956.

Solari, Juan A., La Vanguardia. Su trayectoria histórica. Hombres y luchas, Buenos Aires, Afirmación, 1974.

Periódicos

$A B C$ del Socialismo

El Diario del Pueblo

El Tiempo

La Nación

La Rebelión

La Vanguardia

Documentación manuscrita

Acta de la Asamblea del Centro Socialista Obrero, 17 de mayo de 1895, Fondo José Ingenieros, CeDInCI, A-1-1.

Carta de Juan B. Justo a José Ingenieros, 28 de diciembre de 1895, Fondo José Ingenieros, CeDInCI, A-6-1.

Carta de Alfredo J. Torcelli a José Ingenieros, 12 de noviembre de 1903, Fondo José Ingenieros, CeDInCI, A-6-1

Carta de Alfredo J. Torcelli a José Ingenieros, 25 de septiembre de 1905, Fondo José Ingenieros, CeDInCI, A-6-1

\section{Fuentes secundarias}

Alonso, Paula, "En la primavera de la historia': El discurso político del roquismo de la década del ochenta a través de su prensa", Boletín del Instituto de Historia Argentina y Americana Dr. Emilio Ravignani, № 15, 1997, 35-70. 
Ambroise-Rendu, Anne-Claude, "L' «autre information» dans l'Humanité: le crime, la catastrophe, le sensationnel, 1904-1914", Christian Delporte, Claude Pennetier, Jean-François Sirinelli et al (eds.), l'Humanité de Jaurès à nos jours, Paris, Nouveau Monde, 2004, 43-57.

Beers, Laura, Your Britain. Media and the Making of the Labour Party, Cambridge, Harvard University Press, 2010.

Berensztein, Sergio, Un partido para la Argentina moderna. Organización e identidad del Partido Socialista (1896-1916), Buenos Aires, Documentos CEDES/60, 1991.

Bertagna, Federica, La stampa italiana in Argentina. Roma, Donzelli, 2009.

Courban, Alexandre, l'Humanité de Jean Jaurès à Marcel Cachin (1904-1939), Yvry-sur-Seine, Les editions de l'Atelier, 2015.

Cúneo, Dardo, Juan B. Justo y las luchas sociales en la Argentina, Buenos Aires, Solar, 1997.

Charle, Christophe, Le siècle de la presse: 1830-1939, Paris, Ed. du Seuil, 2004.

de Luis Martín, Francisco y Luis Arias González, Casas del Pueblo y centros obreros en España, Madrid, Editorial Pablo Iglesias, 2009.

Debray, Régis, "El socialismo y la imprenta: un ciclo vital", New Left Review, № 46, 2007, 5-26.

Delhaye, Jean, La Maison du Peuple de Victor Horta, Bruxelles, Atelier Vokaer, 1987.

Dominick, Raymond, "Democracy or Socialism? A case study of Vorwärts in the 1890s", Central European History, Vol. 10, No 4, 1977, 286-311.

Duncan, Tim, "La prensa política: Sud-América, 1884-1892, Gustavo Ferrari y Ezequiel Gallo (comps.), La Argentina del ochenta al Centenario, Buenos Aires, Sudamericana, 1980, 761-783.

García Costa, Víctor, Adrián Patroni y la situación de los trabajadores en la Argentina, Buenos Aires, Docencia, 2011.

Falcón, Ricardo, "Orígenes del movimiento socialista en Argentina. Prólogo. Capítulo I y II", Cuadernos del Ciesal, $\mathrm{N}^{\circ}$ 10, 2011.

Falcón, Ricardo, "Izquierdas, régimen político, cuestión étnica y cuestión social en Argentina (1890-1912)", Anuario, No 12, 1986/7, 365-389.

Gómez, Hernán, "Los diarios como espacios públicos. La Prensa en la vida social de Buenos Aires a comienzos del siglo XX", Intersecciones en Antropología, $\mathrm{N}^{\circ}$ 9, 2008, 261-274.

Laera, Alejandra, "Cronistas, novelistas: la prensa periódica como espacio de profesionalización en la Argentina (1880-1910)", Carlos Altamirano (dir.), Historia de los intelectuales en América Latina I. La ciudad letrada, de la conquista al modernismo, Buenos Aires, Katz, 2008, 495-522.

Malosetti, Laura, Los primeros modernos. Arte y sociedad en Buenos Aires a fines del siglo XIX, Buenos Aires, Fondo de Cultura Económica, 2001.

Maro, Cristóbal, "Adrián Patroni. Aproximación biográfica de un trabajador socialista a fines del siglo XIX”, XI Jornadas Interescuelas/Departamentos de Historia, Tucumán, 2007.

Martinek, Jason, Socialism and Print Culture in America, 1897-1920, London, Pickering \& Chatto, 2012.

Martínez Mazzola, Ricardo, "Campeones del proletariado. El Obrero y los comienzos del socialismo en la Argentina", en Políticas de la Memoria, No 4, verano 2003/2004, 91-110

Martínez Mazzola, Ricardo, "El papel de la prensa en la formación del socialismo en la Argentina (1890-1912)", en VII Congreso Nacional de Ciencia Política, Córdoba, SAAP-Universidad Católica de Córdoba, 2005.

Ojeda Silva, Nahuel. El Tiempo: prensa y política durante la crisis de la Unión Cívica Radical (1896-1905), Tesis de Licenciatura, Universidad Torcuato Di Tella, 2012.

Pan, Luis, Juan B. Justo y su tiempo. Apuntes para una biografía intelectual, Buenos Aires, Planeta, 1991.

Pastormerlo, Sergio, "1880-1899. El surgimiento de un mercado editorial”, José Luis de Diego (dir.), Editores y políticas editoriales en Argentina, 1880-2000, Buenos Aires, Fondo de Cultura Económica, 2006, 1-28. 
Poy, Lucas, "Ciudadanía, derechos políticos y conciencia de clase. La cuestión de la naturalización de los extranjeros en los orígenes del socialismo argentino", Diálogos, Vol. 16 N² 2, 2015, 3-29.

Poy, Lucas, “«Despertar al pueblo trabajador». Los diálogos de Adrián Patroni en La Vanguardia y en el ABC del Socialismo (1896-1900)", Estudios del Trabajo No 49/50, 2015, 133-153.

Prieto, Adolfo, El discurso criollista en la formación de la Argentina moderna, Buenos Aires, Siglo XXI, 2006.

Ramos, Julio, Desencuentros de la modernidad en América Latina, El Perro y la Rana, Caracas, 2009.

Rebérioux, Madeleine, "Le journal de Jaurès", Christian Delporte, Claude Pennetier, Jean-François Sirinelli et al (dirs.), l'Humanité de Jaurès à nos jours, Paris, Nouveau Monde, 2004, 19-42.

Régnier, Philippe, "Le journal militant", Dominique Kalifa, Philippe Régnier, Marie-Ève Thérenty et Alain Vaillant (eds.), La Civilisation du journal. Histoire culturelle et littéraire de la presse française au XIXe siècle, Paris, Nouveau Monde, 2012, 295-316.

Rojkind, Inés, "El gobierno de la calle. Diarios, movilizaciones y política en Buenos Aires del novecientos", Secuencia, 2012, No 84, 99-123

Roman, Claudia, "La modernización de la prensa periódica entre La Patria Argentina (1879) y Caras y Caretas (1898)", Alejandra Laera (dir.), Historia crítica de la literatura argentina. Volumen 3. El brote de los géneros, Buenos Aires, Emecé, 2010, 15-36.

Roth, Guenther, The Social Democrats in Imperial Germany. A study in Working Class-Isolation and National Integration, New Jersey, The Bedminister Press, 1963.

Shore, Elliot, Talkin' Socialism. J. A. Mayland and the Role of the Press in American Radicalism, 1890-1912, Lawrence, University Press of Kansas, 1988.

Silvestre, Charles, Jaurès, la passion du journaliste, Paris, Le Temps des Cerises, 2010.

Tarcus, Horacio, Marx en la Argentina. Sus primeros lectores obreros, intelectuales y científicos, Buenos Aires, Siglo XXI, 2007.

Tarcus (dir.), Horacio, Diccionario biográfico de la izquierda argentina. De los anarquistas a la "nueva izquierda", 1870-1976, Buenos Aires, Emecé, 2007.

Walter, Richard, The Socialist Party of Argentina 1890-1930, Austin, University of Texas, 1979.

Walter, Richard, "The Socialist Press in Turn-of-the-Century Argentina", The Americas, vol. 37, No 1, 1980, 1-24.

Zimmermann, Eduardo, "La prensa y la oposición política en la Argentina de comienzos de siglo: el caso de La Nación y el Partido Republicano”, Estudios Sociales, № 15, 1997, 45-70. 